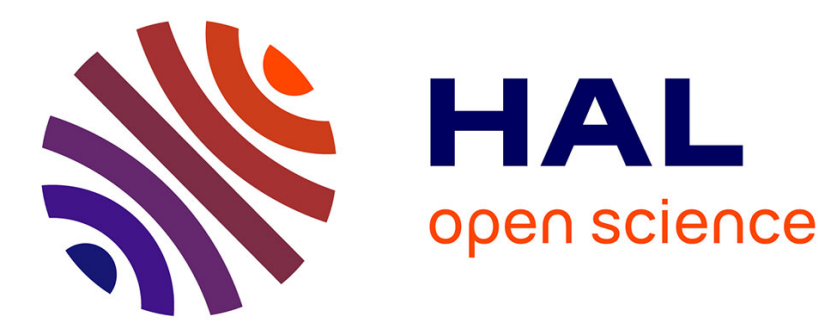

\title{
INTERPRETATION OF DUCTILE FRACTURE TOUGHNESS LOADING RATE DEPENDANCE OF TA6V IN TERMS OF A LOCAL APPROACH
}

Ph. Roudier

\section{- To cite this version:}

Ph. Roudier. INTERPRETATION OF DUCTILE FRACTURE TOUGHNESS LOADING RATE DEPENDANCE OF TA6V IN TERMS OF A LOCAL APPROACH. Journal de Physique IV Proceedings, 1991, 01 (C3), pp.C3-719-C3-725. 10.1051/jp4:19913101 . jpa-00249903

\section{HAL Id: jpa-00249903 https://hal.science/jpa-00249903}

Submitted on 1 Jan 1991

HAL is a multi-disciplinary open access archive for the deposit and dissemination of scientific research documents, whether they are published or not. The documents may come from teaching and research institutions in France or abroad, or from public or private research centers.
L'archive ouverte pluridisciplinaire HAL, est destinée au dépôt et à la diffusion de documents scientifiques de niveau recherche, publiés ou non, émanant des établissements d'enseignement et de recherche français ou étrangers, des laboratoires publics ou privés. 
Colloque C3, suppl. au Journal de Physique III, Vol. 1, octobre 1991

\title{
INTERPRETATION OF DUCTILE FRACTURE TOUGHNESS LOADING RATE DEPENDANCE OF TA6V IN TERMS OF A LOCAL APPROACH
}

\author{
Ph. ROUDIER \\ DGA/Centre de Recherche et d'Etudes d'Arcueil, 16 bis Av. \\ prieur de la Côte d'Or, F-94114 Arcueil cedex, France
}

\begin{abstract}
Fracture of equiaxed Ti-6Al-4V is studied under two different loading rates namely static loading where $\mathrm{K}=1 \mathrm{MPaVm} / \mathrm{s}$ and dynamic loading where $\mathrm{K}=107$ $\mathrm{MPaVm} / \mathrm{s}$. An important increase in fracture tougness is found from static to dynamic loading. The results are interpreted in terms of a the local approach to fracture based on a local criterion of critical void growth. The increase in fracture toughness is explained from an increase in both the yield strength and the notch ductility from static to dynamic loading.

Résumé: $\quad$ La rupture d'un alliage de Titane TA6V présentant une microstructure équiaxe est étudiée sous deux régimes de sollicitation dénomés chargement statique où $\mathrm{K}=1$ $\mathrm{MPaVm} / \mathrm{s}$ et chargement dynamique où $\mathrm{K}=10^{7} \mathrm{MPaVm}$. Une élévation importante de la ténacité est mise en évidence avec l'augmentation de la vitesse de sollicitation. Ces résultats sont interprétés à partir de l'approche locale à la mécanique de la rupture à l'aide d'un critére local de croissance critique de cavitès. La variation de ténacité provient d'une augmentation conjointe de la limite d'écoulement et de la ductilité sous entaille du matériau avec la vitesse de sollicitation.
\end{abstract}

\section{INTRODUCTION}

The field of dynamic fracture comprises both the study of a stationnary crack subjected to very high loading rates and the study of a propagating crack subjected to either static or dynamic loading. This paper focuses on stationnary cracks subjected to either static or dynamic loading giving rise to loading rates respectively of $1 \mathrm{MPaVm} / \mathrm{s}$ and $10^{7} \mathrm{MPaVm} / \mathrm{s}$. Differences in the resistance to crack propagation between static and dynamic loading conditions can arise from a purely mechanical effect of building up of stresses at the crack tip due to wave propagation phenomenum or from inertial effects at the crack tip or from a purely material effect expressed in terms of both deformation and damage kinetics micromechanisms. It is shown that under the loading conditions considered for this study, only the material effects are of significance. Several studies $[1,2]$ have shown that fracture in equiaxed Ti-6Al-4V occurs in a ductile manner with a micromechanism of cavity nucleation, void growth and coalescence leading to a dimpled fracture surface. Such micromechanisms have been extensively studied for the fracture of steels on the ductile plateau, and fracture of A508 steel has been successfully analysed with the local approach to ductile fracture. Fracture behavior of Ti-6Al-4V is found to be highly dependant on the loading rate, though no change in micromechanism of fracture is observed for this particular equiaxed Ti-6Al-4V. Therefore the concept of a critical void growth criterion $\mathbf{R}_{\mathbf{c}} / \mathbf{R}_{\mathbf{0}}$ with a characteristic distance $\Delta \mathbf{a}_{\mathbf{c}}$ is used to express fracture of Ti-6Al-4V under both static and dynamic loading. 


\section{MATERIAL AND EXPERIMENTAL PROCEDURES}

Material:

The material investigated in this study is an equiaxed Ti-6Al-4V provided in the form of laminated plates of thickness $e=50 \mathrm{~mm}$. The thermomechanical treatment received consist of an $\alpha / \beta$ transformation with heat treatment $730^{\circ} \mathrm{C} / 2 \mathrm{~h}$. This material does not contain any form of inclusion but is rather formed of $\alpha$-phase grains (hcp structure) surrounded by a three-dimensionnal network of $\beta$-phase (bcc structure ). The deformation incompatibilities between these two phases are known to induce possible twinning and stress concentration at the $\alpha / \beta$ interface during deformation process [3]. The grain size varies between 15 $\mu \mathrm{m}$ and $20 \mu \mathrm{m}$ with the presence of some more elongated grains in the laminate direction (Figure 1 ).

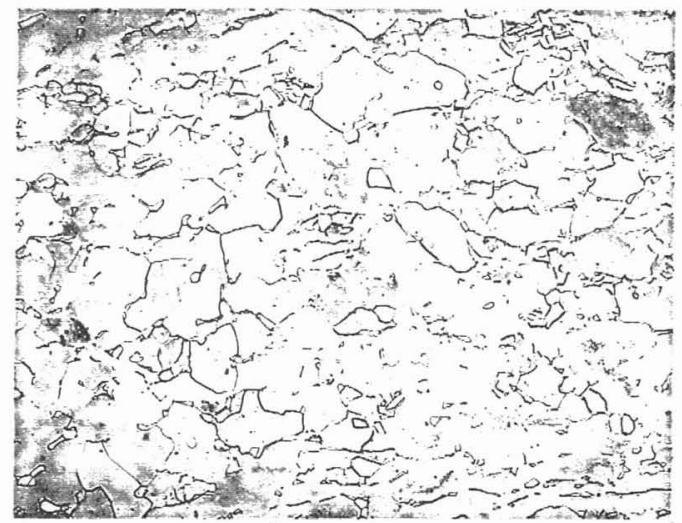

Figure 1 : Typical microstructure of equiaxed Ti-6Al-4V.(*300)

\section{Experimental procedures:}

\section{Mechanical behavior}

All the samples used are of axisymmetric shape with the axis along the tranverse direction of the plate. They are taken from the mid-section of the laminated plate.

Compression tests have been performed on small cylinders with diameter $\phi=10 \mathrm{~mm}$ and height $\mathrm{h}$ $=12 \mathrm{~mm}$ with annular groves on the opposite faces to avoid buckling during testing. Corresponding constitutive laws have been obtained under static as well as under dynamic loading with the Hopkinson bars apparatus documented elsewhere [4]. Corresponding deformation rates are $\dot{\varepsilon}=10^{-3} \mathrm{~s}^{-1}$ under static loading and $\dot{\varepsilon}=10^{3} \mathrm{~s}^{-1}$ under dynamic loading. Tensile tests on axisymmetric specimen of diameter $\phi=7$ $\mathrm{mm}$ have also been performed under static loading.

\section{Fracture toughness}

Fracture toughness has been determined with axisymmetric tensile specimen of diameter $\phi=14$ $\mathrm{mm}$, notched and fatigue precracked under rotating bending to a depth $\mathbf{a} / \mathbf{R}=0.45$, with $\mathbf{a}$ the fatigue crack length and $\mathbf{R}$ the radius of the sample (Figure 2). Very good annular fatigue cracks have been obtained. Static tests were performed with two facing extensometers to record the crack mouth opening curves during the test, the load is monitored through the load cell. Load versus crack mouth opening have been derived and $\mathrm{J}$-integral values calculated with the Merkle formula [5] : 


$$
\mathbf{J}=\frac{1}{2 \Pi \mathbf{c}^{2}}\left[-\mathbf{P} \delta_{\text {crack }}+3 \int_{0}^{\delta_{\text {wax }}} \mathbf{P d} \delta_{\text {crack }}\right]
$$

where $\mathbf{c}$ is the radius of the uncracked ligament prior to testing, $\mathbf{P}$ is the recorded load and $\delta_{\text {crack }}$ the opening due to the presence of the crack

$$
\delta_{\text {crack }}=\delta_{\text {experiment }}-\frac{\mathbf{L}_{\mathrm{o}} \mathbf{P}}{\Pi \mathbf{R}^{2} \mathbf{E}}
$$

where $\mathbf{L}_{\mathbf{0}}$ is the reference length of the extensometer, $\mathbf{E}$ the Young modulus. It is assumed that no stable crack growth occurs before final fracture, as confirmed from FEM of the test. The value of $\mathbf{J}$ at failure is therefore considered to be a measure of fracture toughness $\mathbf{J}_{\mathbf{I}}$.

Dynamic tensile test on identical axisymmetric precracked specimen have been conducted on a specially designed apparatus called "Arbaléte" [6]. A projectile is accelerated on parallel guides by rubber bands to speeds up to $50 \mathrm{~m} / \mathrm{s}$. One end of the sample is screwed on a moving head which is impacted by the projectile, generating a high tensile pulse with a rising duration of $25 \mu \mathrm{s}$. The second head is fixed to a long bar instrumented with a strain gage at $500 \mathrm{~mm}$ from the sample. The specimen is instrumented with two strain gages at $20 \mathrm{~mm}$ on each side from the crack plane. An optical extensometer ZIMMER (Darmstadt RFA) is used to measure the displacements of two interfaces painted on the sample at $3 \mathrm{~mm}$ on each side from the crack plane. Though in a previous study on dynamic fracture of steels [6] the load recorded from the strain gage on the transmitted bar was used to derive load-crack mouth opening curves, it was found here that in the case of Titanium specimen this would lead to overestimate the load carried out by the uncracked ligament. Numerical investigations with the FEM code ABAQUS have shown that a good insight is gained using the displacement of the second interface (with respect to pulse motion) to obtain the stress acting over that section through the theory of uniaxial motion of waves in a cylinder:

$$
\sigma=\sqrt{\rho \mathbf{E}} \partial \mathbf{u} / \partial \mathbf{t}
$$

Then a load is derived and the Merkle formula (1) is used to establish a J-integral formulation. The value of the J-integral at fracture is taken as the value corresponding to the time when the second interface starts to decelerate.

\section{Ductility as a function of stress triaxiality}

In order to determine the influence of stress state on the ductility at failure and to calculate the critical void growth $\mathbf{R}_{\mathbf{c}} / \mathbf{R}_{\mathbf{0}}$ tests on axisymmetric notched tensile specimen with different notch radius have been performed under static and dynamic loading (Figure 2). The use of the these specimen is now well-established since the early studies of BEREMIN [7]. These specimens allow proportionnal loading within a large volume of material at the center of the specimen under various states of triaxiality. For the use of the concept of a critical void growth at the tip of a crack where the stress triaxiality varies quite significantly, it is necessary to evaluate the dependance of $\mathbf{R}_{\mathbf{c}} / \mathbf{R}_{\mathbf{0}}$ with stress triaxiality. Numerical calculations through FEM give the ductulity at failure $\varepsilon_{\mathbf{R}}$ in the minimum section from the knowledge of the overall strain at failure

$$
\overline{\varepsilon_{F}}=2 \ln \left(\phi_{0} / \phi_{F}\right)
$$

where $\phi_{0}$ is the initial diameter of the minimum section and $\phi_{F}$ the diameter of that section at failure. These numerical calculations also determine the stress triaxiality $\sigma_{\mathbf{m}} / \sigma_{\mathbf{e q}}$ in the minimum section where $\sigma_{\mathbf{m}}$ is the mean stress and $\sigma_{\mathrm{eq}}$ is the equivalent Von-Mises stress. 
Cavity nucleation is assumed to take place in the early stages of plasticity and the strain necessary for cavity nucleation is taken as 0 . Void growth is then calculated by integration of the Rice and Tracey expression $[8,9]$

$$
\mathbf{d R} / \mathbf{R}=0,283 \exp \left(\frac{3}{2} \frac{\sigma_{\mathrm{m}}}{\sigma_{\mathrm{eq}}}\right) \mathbf{d} \varepsilon_{\mathrm{eq}}
$$

from 0 to $\varepsilon_{\mathbf{R}} . \mathbf{R}_{\mathbf{c}} / \mathbf{R}_{\mathbf{0}}$ is then obtained from the mesh cell within the minimum section where $\mathbf{R} / \mathbf{R}_{\mathbf{0}}$ is the largest at the time of failure.
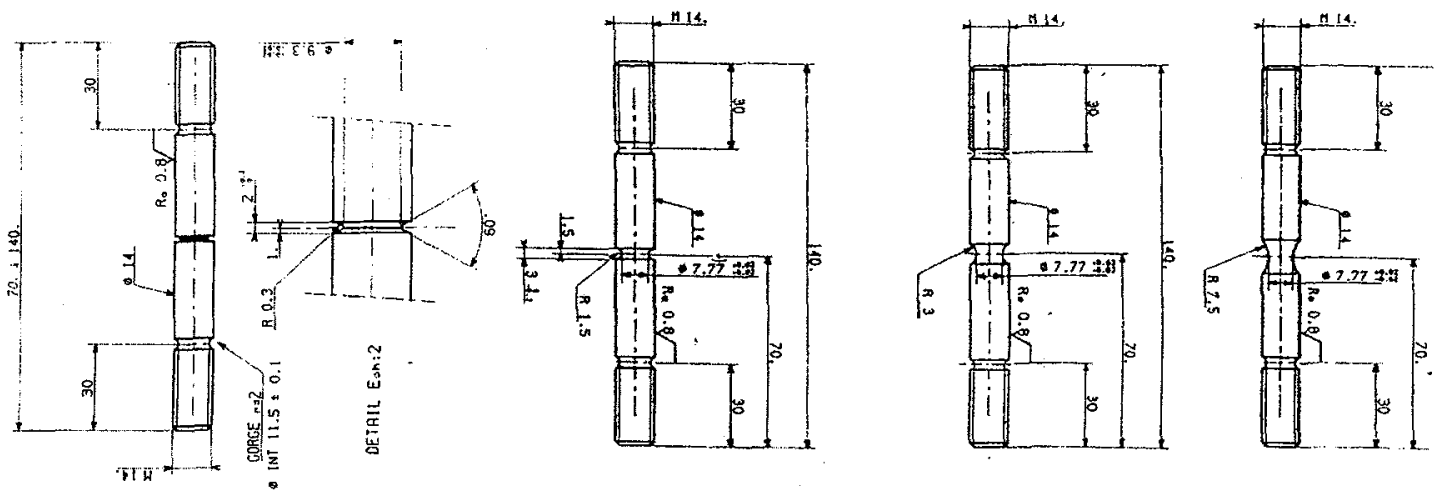

Figure 2: Fracture toughness specimen and notched axisymmetric specimen AER2, AER4, AER10.

\section{RESULTS}

Constitutive laws are reported Figure 3. An increase in yield strenght of the order of $50 \%$ is found in compression loading with the increase of deformation rate. A similar phenomenum is assumed to occur under tensile testing.

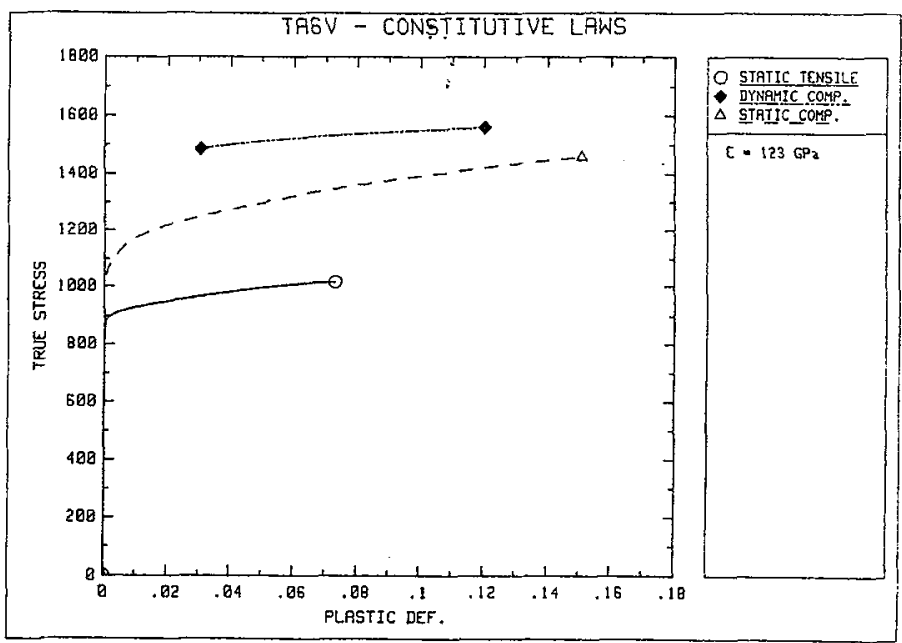

Figure 3: Constitutive laws, static tensile, static compression , dynamic compression. 
Notched specimen ductilities are given Table 1 . An increase of about $75 \%$ is found for the different stress triaxiality conditions. Numerically calculated critical void growth rate are reported Figure 4 for static conditions A critical value $\mathbf{R}_{\mathbf{c}} / \mathbf{R}_{\mathbf{o}}$ of $\mathbf{1 . 2 9}$ can be derived as a mean value.

\begin{tabular}{|c|c|c|c|c|c|}
\hline specimen & AER 2 & AER 4 & AER 10 & \multicolumn{1}{|c|}{ AE0 } & AE0 \\
\hline$\varepsilon_{\mathrm{F}}$ static & 0.144 \\
\hline$\varepsilon_{\mathrm{F}}$ dynamic & 0.182 & 0.243 & $\mathrm{~K}_{\mathrm{J}}$ static. & $73 \mathrm{MPaVm}$ \\
\hline 0.267 & 0.307 & 0.423 & $\mathrm{~K}_{\mathrm{J}}$ dynamic. \\
\hline $120 \mathrm{MPaVm}$ \\
\hline
\end{tabular}

Table 1

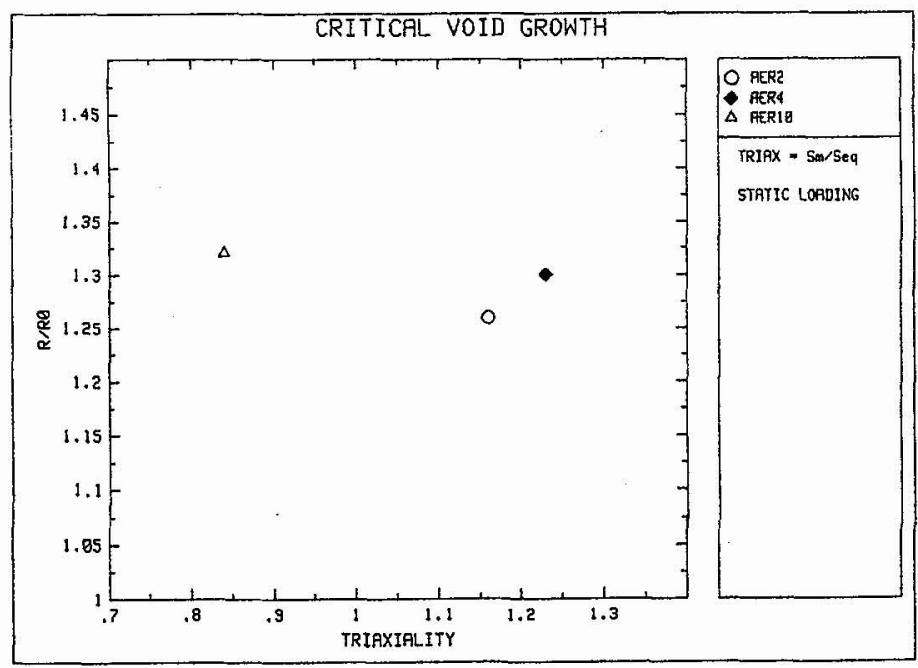

Figure 4: Critical $\mathbf{R} / \mathbf{R}_{\mathbf{0}}$ (static loading)

Fracture toughness results are reported Table 1 for both static and dynamic conditions. These are $\mathrm{K}_{\mathrm{J}}$ values with $\mathbf{K}_{\mathbf{J}^{2}}=\mathbf{E} . \mathbf{J} /\left(\mathbf{1 -} \boldsymbol{v}^{\mathbf{2}}\right)$ as a plane strain state of stress prevails within the axisymmetric specimen. The result is an increase of about $65 \%$ in fracture toughness for this material with an increase of loading rate from $1 \mathrm{MPaVm} / \mathrm{s}$ to $10^{7} \mathrm{MPaVm} / \mathrm{s}$.

Fracture surface appearances are very similar with a dimple type fracture surface for the two loading rates considered. (Figure 5) There is no evidence of any difference in the dimple sizes, but as shown by Lautridou [10] final dimples result from the instable flow localization process occuring during void coalescence, and are not directly related to critical void growth rate which is the controlling parameter of fracture.
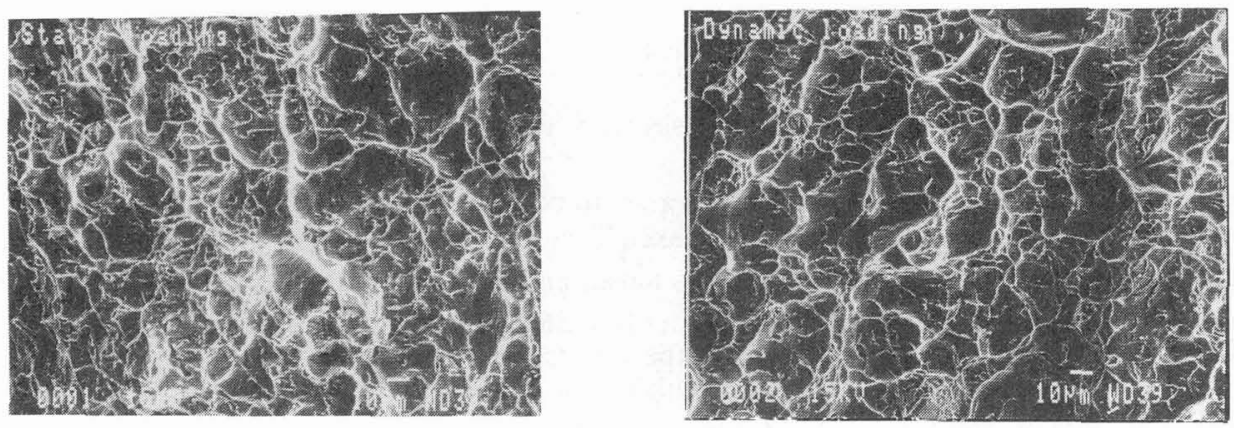

Figure 5: Fracture surfaces (1) static loading, (2) dynamic loading. 


\section{DISCUSSION}

Mudry [11] has shown that it is possible to relate $\mathrm{J}_{\mathrm{Ic}}$ values with metallurgical factors such as inclusion distribution, using as a local rupture criterion the calculated value of void growth at failure $\mathbf{R}_{\mathbf{c}} / \mathbf{R}_{\mathbf{0}}$. The relation can be writen in the form

$$
\mathbf{J}=\alpha \Delta \operatorname{ac} \sigma_{\mathbf{y}} \ln \left(\mathbf{R}_{\mathrm{c}} / \mathbf{R}_{\mathbf{o}}\right)
$$

where $\alpha=4.5, \sigma_{\mathbf{y}}$ is the yield strength of the material and $\Delta \mathbf{a}_{\mathbf{c}}$ is a characteristic distance. $\Delta \mathbf{a}_{\mathbf{c}}$ can be either derived from microstructural analysis through

$$
\Delta \mathbf{a c}=\sqrt[2 / 3]{\mathbf{N}_{\mathbf{v}}}
$$

where $\mathbf{N}_{\mathbf{v}}$ is the number of inclusions per unit volume or taken as the size of the square finite element mesh located at the crack tip such as $\mathbf{R} / \mathbf{R}_{\mathbf{0}}$, calculated within this cell at failure is equal to $\mathbf{R}_{\mathcal{C}} / \mathbf{R}_{\mathbf{o}}$ obtained from the analysis of notch ductility.

In the case of Titanium $\Delta \mathbf{a}_{\mathbf{c}}$ cannot be obtained from microstructural analysis. Numerical simulations were runned for axisymmetric cracked specimen under static tensile loading with a mesh of square 4nodes cells at the crack tip to evaluate $\mathbf{R} / \mathbf{R}_{\mathbf{0}}$ within the first cell at the crack tip at the time of failure. Very good agreement was found between experimental and simulated load-crack mouth opening curves. Figure 6 describes the value of $\mathbf{R} / \mathbf{R}_{\mathbf{0}}$ versus crack mouth opening for different sizes of the mesh cell at the crack tip i.e. different values of $\Delta \mathbf{a}_{\mathbf{c}}$. A value of $\mathbf{R} / \mathbf{R}_{\mathbf{0}}$ of $\mathbf{1 . 2 9}$ is attained at failure in this cell for a cell length $\Delta \mathbf{a}_{\mathbf{c}}=35 \mu \mathrm{m}$ (Figure 6).

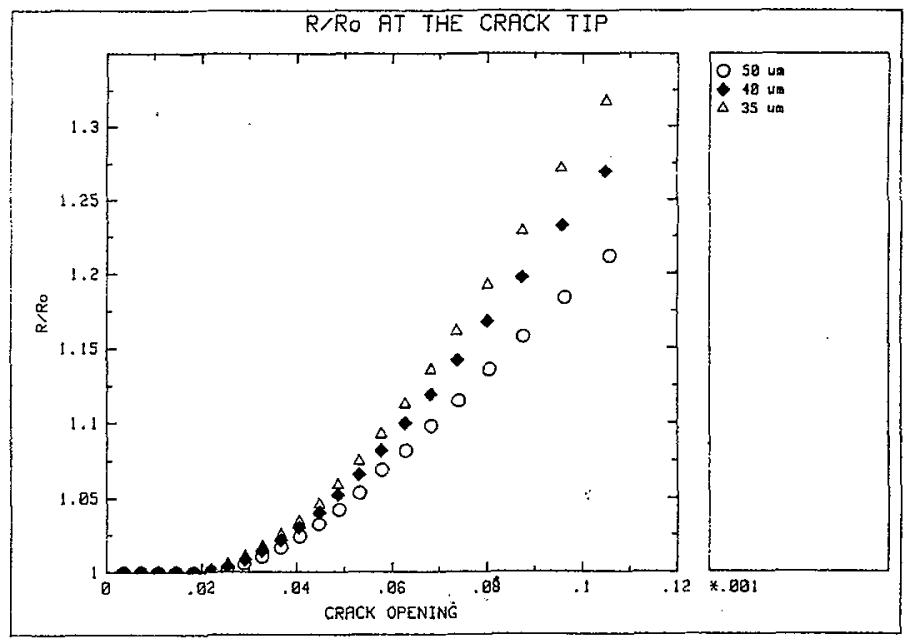

Figure 6: $\mathbf{R} / \mathbf{R o}$ in the cell at the crack tip as versus crack mouth opening for different mesh sizes.

It can be noted that this value of $\Delta \mathbf{a}_{\mathbf{c}}$ is rather small.compared to values obtained in the case of steels, but the materials are quite different. The equiaxed Titanium presents a small grain size which leads to numerous initiation sites for cavity nucleation as thoses are located at the interface between $\alpha$ and $\beta$ phases. From theses values $J_{I C}$ can be estimated from (3) to $36 \mathbf{~ k J} / \mathbf{m}^{2}$ which gives a value of $K_{\mathbf{J}}$ equal to $70 \mathrm{MPaV}$ for plane strain which is close to the experimental value of $73 \mathrm{MPaVm}$.

Numerical simulations are much more difficult to run in the case of dynamic loading. As a first approximation the parameters of formula (3) can be evaluated as follow. $\Delta \mathbf{a}_{\mathbf{c}}$ is representative of the distribution of growing initiated cavity sites. Though Titanium is known to allow for more extensive 
twinning under the same amount of deformation under dynamic loading then under static loading [3], no evidence was found for any change in type nor in distribution of initation sites from static to dynamic loading. Therefore $\Delta \mathbf{a}_{\mathbf{c}}$ could be kept equal to the value of $35 \mu \mathrm{m}$. The yield strenght cannot be readily obtained under dynamic loading, but a 50\% increase can be expected from the compression tests conducted. Notch ductility has been shown to increase by about $75 \%$ between static and dynamic loading. This gives an increase in the critical void growth rate $\mathbf{R}_{\mathbf{c}} / \mathbf{R}_{\mathbf{0}}$. As

$$
\ln \left(\mathbf{R}_{\mathrm{c}} / \mathbf{R}_{\mathrm{o}}\right)=0,283 \int_{\mathrm{o}}^{\varepsilon_{\mathrm{z}}} \exp \left(\frac{3}{2} \frac{\sigma_{m}}{\sigma_{\mathrm{eq}}}\right) \mathrm{d} \varepsilon_{\mathrm{eq}}
$$

one can see that $\ln \left(\mathbf{R}_{\mathbf{c}} / \mathbf{R}_{\mathbf{o}}\right)$ is also highly dependant on stress triaxiality for the same amount of equivalent plastic strain prior to failure. Good numerical simulations are necessary to get good estimates of $\mathbf{R}_{\mathbf{c}} / \mathbf{R}_{\mathbf{0}}$., and they rely on precise constitutive laws for tensile loading which are still to be determined. Therefore a rough estimate of $\ln \left(R_{c} / R_{0}\right.$.) under dynamic loading will be taken assuming a $75 \%$ increase from the $\ln \left(\mathbf{R}_{\mathbf{c}} / \mathbf{R}_{\mathbf{o}}\right.$ ) value obtained for static loading, to compare with the increase of notch ductility. This would give a value of $\mathbf{1 . 5 6}$ for $\mathbf{R}_{\mathbf{c}} / \mathbf{R}_{\mathbf{0}}$. under dynamic loading. A value of $\mathbf{J}_{\mathbf{I c}}$ under dynamic loading can then be estimated from (3) to be equal to $95 \mathrm{~kJ} / \mathrm{m}^{2}$, and a corresponding value for $K_{\mathfrak{J}}$ of $113 \mathrm{MPa} \sqrt{\mathrm{m}}$. This value compares favorably with the experimental result of $120 \mathrm{MPaVm}$.

\section{CONCLUSION}

Fracture of equiaxed Ti-6Al-4V under loading rates of $1 \mathrm{MPaV} \overline{\mathrm{m}} / \mathrm{s}$ and $10^{7} \mathrm{MPaVm} / \mathrm{s}$ can be interpreted in terms of a mechanismof cavity nucleation, void growth and coalescence. No change has been observed in neither the mechanism for cavity nucleation nor the hole growth process leading to failure. The important increase in fracture toughness $(65 \%)$ with the loading rate can be interpreted from the increase in yield strength and the increase of notch ductility. Fracture would then proceed in the material when a critical void growth rate of 1.29 is attained at the tip of a crack over a distance of $35 \mu \mathrm{m}$ under static loading and of 1.56 over the same distance in the case of dynamic loading. Further experiments on other specimen geometries should be conducted to validate theses results.

\section{REFERENCES}

[1] Y. Krishnamohandro, V.V. Kutumbarai, P. Rama Rao, Acta Metallurgica Vol $34 \mathrm{n}^{\circ} 9 \mathrm{pp} 1783-$ 1806, (1986).

[2] A. Gysler, G. Luterjering in Titanium Science and Technology, Proceedings of the Fifth International Conference on Titanium pp 2001-2014 (1984).

[3] S. Gabelotaud, "Comportement sous sollicitations statiques et dynamiques du Titane pur et de deux de ses alliages", Thèse de Docteur-Ingénieur Université d'Orsay (1990).

[4] P. Bensussan, J. Clissson, N. Gabard, L. Penazzi, "Présentation des essais dynamiques aux barres d'Hopkinson", stage ENSTA/DYMAT M10.

[5] J. R. Rice, P. C. Paris, J. G. Merkle, ASTM STP 536 PP 231-245 (1973).

[6] P. Bensussan, Journal de Physique, Colloque C3 Supplément n ${ }^{\circ} 9$ Tome 49 pp 199-206 (1988).

[7] BEREMIN in "Three dimensionnal constitutive relationsand ductile fracture", North-Holland Publishing Compagny pp 185-205 (1981).

[8] J. R. Rice, D. M. Tracey, J. Mech. Phys. Solids Vol 17 pp 201-217 (1969).

[9] B. Marini, F. Mudry, A. Pineau, Engineering Fracture Mechanics Vol 22 n 3 pp 375-386 (1985).

[10] J. L. Lautridou "Etude de la déchirure ductile d'aciers à faible résistance. Influence de la teneur inclusionnaire", Thése de Docteur Ingénieur Ecole des Mines de Paris (1980).

[11] F. Mudry, "Etude de la rupture ductile et de la rupture par clivage d'aciers faiblement alliés", Thése de Doctorat d'état Université de Compiegne (1982). 